\title{
PENGARUH STRATEGI PEMBELAJARAN SIMULASI DAN KEMANDIRIAN BELAJAR TERHADAP HASIL BELAJAR PENDIDIKAN AGAMA ISLAM SISWA SEKOLAH MENENGAH ATAS NEGERI 6 PEMATANG SIANTAR
}

\author{
Rusyadi \\ Penulis adalah Guru Sekolah Menengah Atas Negeri 6 \\ Pematang Siantar
}

\begin{abstract}
The objectives of this quasi experimental research were to discover applying whether: (1) the learning achievement of students' Islamic eduction taught by applying simulation instructional strategy were higher than students' learning achievement in Islamic education taught by applying expository instructional strategy, (2) the learning achievement of students' Islamic education with high learning student independent than the learning achievement of students' Islamic education with low learning student independent, and (3) there was are an interaction between instructional strategy and learning student independentin affecting the learning achievement of students' Islamic education. The population of this study was all Grade XI students, State School Six, Pematang Siantar regency, Based on cluster random sampling technique, one class was chosen to be taught by applying simulation instructional strategy dan expository strategy..The research findings releaved that: (1) on average the students' learning achievement taught by applying simulation instructional strategy $\bar{X}=28.12$ higher than the average students' learning achievement taught by applying expository learning strategy $\bar{X}=27.00$ with $\mathrm{F}_{\text {count }}=113.96>\mathrm{F}_{\text {table }}=3.984$, (2) on average the students' learning achievement with high learning student independent was $\bar{X}=29.61$ higher than the learning learning student independent with low $\bar{X}=25.93$ with $\mathrm{F}_{\text {count }}=$ $7.66>\mathrm{F}_{\text {table }}=3.984$, and (3) there was an interaction between instructional strategy and learning learning student independent toward learning achievement in Islamic education with $\mathrm{F}_{\text {count }}=35.48>\mathrm{F}_{\text {table }}=3.984$.
\end{abstract}

\section{Kata kunci: Strategi Pembelajaran Simulasi, Kemandirian Belajar, Hasil Belajar}

\section{PENDAHULUAN}

Pemilihan strategi pembelajaran yang tepat, harapan-harapan peningkatan mutu dan hasil belajar dapat dipenuhi. Untuk itu dituntut kemampuan guru untuk merencanakan, merancang, melaksanakan dan mengevaluasi serta melakukan feedback menjadi faktor penting guna mencapai keberhasilan tujuan pembelajaran. Kemampuan guru menguasai materi pembelajaran, gaya mengajar, penggunaan media, penentuan strategidan pemilihan strategi pembelajaran merupakan usaha-usaha untuk melancarkan proses pembelajaran dan meningkatkan hasil pencapaian tujuan pembelajaran. 
Siswa dapat belajar dengan baik apabila strategi pembelajaran dilakukan secara tepat dan efektif. Tepat dimaknai bahwa strategi dan strategi pembelajaran hendaknya disesuaikan dengan karakteristik materi ajar sedangkan efektif di maknai bahwa strategi dan strategi pembelajaran yang diterapkan dapat meningkatkan hasil belajar.

Strategi pembelajaran yang digunakan guru-guru selama ini belum optimal sehingga menyebabkan timbulnya kebosanan siswa yang berakibat rendahnya hasil belajar. Untuk mengurangi atau bahkan menghindari strategi pembelajaran yang terlalu monoton diupayakan berbagai strategi pembelajaran yang lebih efektif dalam menciptakan komunikasi yang multi arah, sehingga diharapkan juga menimbulkan dan meningkatkan interaksi yang proaktif dalam pembelajaran. Namun perlu disadari bahwa strategi tersebut tidak ada yang terbaik atau buruk, karena strategi pembelajaran tersebut memiliki kelebihan dan kekurangan.

Salah satu strategi yang dapat diterapkan dalam pembelajaran PAI adalah strategi simulasi. Pemilihan dan penerapan strategi pembelajaran simulasi dalam pembelajaran PAI dilakukan sesuai dengan karakteristik dari mata pelajaran itu sendiri yang memerlukan keterampilan berpikir dan keterampilan berinteraksi dari siswa untuk memahami materi-materi yang terkandung di dalamnya.

Strategi pembelajaran yang tepat di dalam mempelajari materi PAI digunakan adalah strategi pembelajaran simulasi, di mana dalam kegiatan pembelajaran simulasi dikembangkan kemampuan berpikir, keterampilan intelektual, berinteraksi, bekerja sama guna pemecahan masalah serta belajar tentang berbagai peran dengan melibatkan diri dalam pengalaman nyata atau simulasi dan menjadi peserta didik yang otonom dan mandiri.

Hasil belajar suatu kegiatan pembelajaran juga dipengaruhi oleh karakteristik siswa dalam hal ini adalah kemandirian belajar. Kemandirian belajar terkait dengan prilaku siswa untuk melakukan aktivitas belajar secara mandiri, di mana perbedaan kemandirian yang melekat pada diri siswa berakibat pada perbedaan kemampuan siswa dalam menyerap materi ajar PAI. Dalam hal ini siswa yang dengan kemandirian tinggi akan memberikan dampak untuk berinisiatif, kemauan belajar kuat serta kesiapan belajar yang dapat di atas sendiri tanpa tergantung dengan orang lain, hal ini sebaliknya terjadi pada siswa dengan tingkat kemandirian rendah.

Tingkat kemandirian antara siswa dengan tingkat kemandirian tinggi dan siswa dengan tingkat kemandirian rendah hal ini diduga memberikan pengaruh yang 
berbeda terhadap perolehan hasil belajar siswa. Hal ini disebabkan karakteristik siswa dengan tingkat kemandirian tinggi memiliki tingkat kemandirian tinggi mengerjakan dengan sungguh-sungguh tugas yang diberikan guru karena hal tersebut menantangnya untuk mencari penyelesaian sedangkan siswa dengan tingkat kemandirian rendah cenderung mengharapkan dan membutuhkan bantuan guru atau orang lain dalam menyelesaikannya.

Pemilihan strategi pembelajaran yang tepat dibutuhkan dan harus disesuaikan dengan kemandirian belajar siswa, karena mempelajari materi PAI yang cukup padat dituntut kemandirian belajar siswa dalam mencari sumber-sumber lain. Oleh karena itu, kemandirian belajar siswa adalah salah satu komponen yang harus diperhatikan dengan seksama oleh guru dalam mengidentifikasi kemampuan yang dimiliki peserta didiknya yang akan membantu dalam menentukan materi, strategi, metode dan media yang tepat untuk digunakan. Hal ini perlu dilakukan agar pembelajaran yang disampaikan dapat menarik perhatian siswa dan setiap detik yang berlangsung dalam kegiatan pembelajaran yang dilakukan akan bermakna dan tidak membosankan bagi siswa.

\section{KAJIAN TEORI}

Belajar berasal dari kata ajar yang berarti mencoba (trail) yaitu kegiatan mencoba sesuatu yang belum atau tidak diketahui (Shaffat, 2009:1). Dalam hal ini belajar identik dengan aktivitas membaca sesuatu yang tertulis ataupun yang tidak tertulis sehingga dapat membawa seseorang mengetahui sesuatu yang sebelumnya tidak diketahui.

Singer sebagaimana dikutip Siregar dan Nara (2011:4) menjelaskan belajar adalah perubahan prilaku yang relatif tetap disebabkan praktek atau pengalaman yang sampai dalam situasi tertentu. Selanjutnya Siregar dan Nara (2011:4) mengutip pendapat Burton menjelaskan belajar adalah proses perubahan tingkah laku pada diri individu karena adanya interaksi antara individu dengan individu dan individu dengan lingkungannya sehngga lebih mampu berinteraksi dengan lingkungannya.

Aunurrahman (2011:36) menjelaskan belajar merupakan interaksi individu dengan lingkungannya berupa manusia atau objek-objek lain yang memungkinkan individu memperoleh pengalaman-pengalaman atau pengetahuan, baik pengalaman atau pengetahuan baru maupun sesuatu yang pernah diperoleh atau ditemukan 
sebelumnya akan tetapi menimbulkan perhatian kembali bagi individu tersebut sehingga memungkinkan terjadinya interaksi.

Mardianto (2009;35) menjelaskan belajar adalah suatu usaha atau kegiatan yang bertujuan untuk mengadakan perubahan di dalam diri seseorang mencakup perubahan tingkah laku, sikap, kebiasaan, ilmu pengetahuan, keterampilan dan sebagainya. Sementara itu belajar menurut Sopiatin dan Sahrani (2011:66) adalah proses perubahan tingkah laku, baik dari segi pengetahuan, keterampilan, maupun sikap, dari tidak tahu menjadi tahu, dan tidak mengerti menjadi mengerti, dari ragu menjadi yakin, dengan kata kata keberhasilan belajar ditandai dengan terjadi perubahan tingkah laku pada diri individu yang belajar.

Definisi hasil belajar dijelaskan Dimyati dan Mudjiono, (1999:3) yaitu hasil dari suatu interaksi tindak belajar dan tindak mengajar Sementara itu Djamarah dan Zain (2002:59) menjelaskan bahwa hasil belajar adalah penguasaan peserta didik terhadap bahan/materi pelajaran yang telah guru berikan ketika proses mengajar berlangsung.

Nurmawati (2016:53) menjelaskan hasil belajar merupakan segala prilaku yang dimiliki peserta didik sebagai akibat dari proses belajar yang ditempuhnya. Perubahan tersebut mencakup aspek tingkah laku secara menyeluruh baik aspek kognitif, afektif dan psikomotorik. Senada dengan penjelasan ini, Syah (2010:148) menjelaskan hasil belajar meliputi segenap ranah psikologis yang berubah sebagai akibat dari pengalaman dan proses belajar siswa baik yang berdimensi cipta, dan rasa maupun yang berdimensi karsa.

Hasil belajar merupakan perolehan prestasi yang dicapai secara maksimal oleh siswa. Belajar merupakan proses atau kegiatan yang dijalani secara sadar untuk mendapatkan perubahan, baik dalam bentuk pengetahuan, ketrampilan ataupun sikap. Hasil belajar merupakan prestasi yang dicapai siswa oleh karena adanya usaha sadar yang dilakukan siswa untuk mendapatkan perubahan, baik dalam bentuk pengetahuan, ketrampilan dan sikap. Hasil belajar merupakan kesanggupan untuk berbuat sesuatu sesuai dengan pengetahuan, pengalaman dan ketrampilan yang telah mereka miliki. Dengan demikian, semakin banyak perolehan prestasi yang dimiliki siswa maka semakin tinggi pula tingkat kesanggupan siswa untuk berbuat pada masa akan datang.

Simulasi berasal dari kata simulate yang berarti pura-pura atau berbuat seolaholah. Kata simulation artinyaa tiruan atau perbuatan yang pura-pura, dengan demikian 
pembelajaran simulasi adalah sebagai cara untuk menjelaskan sesuatu (bahan pelajaran) melalui perbuatan yang bersifat pura-pura atau melalui proses tingkah laku imitasi atau bermain peranan mengenai suatu tingkah laku yang dilakukan seolah-olah dalam keadaan yang sebenarnya (Sudjana, 2002:89).

Sudjana (2001:112) menjelaskan simulasi adalah cuplikan sutau situasi kehidupan nyata yang diangkat ke dalam kegiatan pembelajaran. Untuk itu terdapat dua hal yang harus dipertimbangkan yaitu: (1) simulasi disusun sevata sederhana dan dapat dilaksanakan oleh peserta didik, dan (2) didasarkan atas kebutuhan dan tujuan yang dinyatakan oleh peserta didik. Sementara itu menurut Suparman (2012:257) simulasi adalah menampilkan simbol-simbol atau peralatan yang menggantikan proses, kejadian, atau benda yang sebenarnya.

Pembelajaran simulasi merupakan penerapan dari prinsip sibernetik (cybernetic) sebagai salah satu cabang dari psikologi (Aunurrahman, 2011:170). Psikologi cybernetic menganalogikan manusia sebagai suatu sistem kontrol yang mengerakkan jalannya tindakan dan membenarkan arah atau mengoreksi tindakan tersebut dengan pengertian umpan balik. Menurut psikologi cybernetic, tingkah laku manusia mencakup pola gerak yang dapat diamati baik berupa tingkah laku tak tampak seperti pikiran ataupun tingkah laku tampak. Pada bermacam-macam situasi yang diberikan, individu memodifikasi tingkah laku sesuai dengan umpan balik yang mereka terima dari lingkungannya. Pola gerak dan responnya diorganisasikan dengan sistemnya, kemampuan menerima umpan balik merupakan sistem mekanisme manusia untuk menerima dan menggunakan informasi.

Strategi pembelajaran ekspositori adalah strategi pembelajaran yang menekankan kepada proses penyampaian materi secara verbal dari seorang guru kepada sekelompok siswa dengan maksud agar siswa dapat menguasai materi pelajaran secara optimal (Sanjaya, 2014:179).

Gulo (2008:11) menjelaskan strategi pembelajaran ekspositori dilakukan guru mengolah secara tuntas pesan/materi sebelum disampaikan di kelas sehingga peserta didik tinggal meneria saja. Rusmono (2012:66) menjelaskan strategi pembelajaran merupakan bentuk dari pendekatan pembelajaran yang berorientasi kepada guru, karena dalam strategi ini guru memegang peran yang sangat dominan. Melalui strategi ini guru menyampaikan materi pelajaran secara terstruktur dengan harapan materi pelajaran yang disampaikan dapat dikuasai siswa dengan baik. 
Brady sebagaimana dikutip Rusmono (2012:67) menjelaskan strategi pembelajaran adalah strategi yang terpusat kepada guru dengan fokus pendekatan melalui ceramah (naration), penjelasan serta penggunaan latihan dan perbaikan dalam mengkoordinir belajar siswa. Hal ini sejalan dengan penjelasan Sagala (2012:78) bahwa strategi pembelajaran ekspositori bertolak dari pandangan, tingkah laku kelas dan penyebaran pengetahuan dikontrol dan ditentukan oleh guru/ pengajar. Siswa dipandang sebagai objek yang menerima apa yang diberikan guru.

Strategi pembelajaran ekspositori merupakan strategi pembelajaran di mana guru menyampaikan informasi secara verbal kepada siswa. Pada strategi ini proses pembelajaran yang terpusat kepada guru dan guru merupakan sumber informasi utama (Barry dan King dalam Rusmono, 2012:66). Hal ini sejalan dengan penjelasan Jacobsen, Eggen dan Kauchak bahwa strategi pembelajaran ekspositori merupakan proses pembelajaran yang lebih berpusat kepada guru (teacher centered), guru menjadi sumber dan pemberi informasi utama (Rusmono, 2012:66).

Kemandirian belajar merupakan kesatuan konsep yaitu kemandirian dan belajar. Kemandirian ialah keadaan dimana seseorang memiliki hasrat bersaing untuk maju demi kebaikan dirinya, mampu mengambil keputusan dan inisiatif untuk mengatasi masalah yang dihadapi, memiliki kepercayaan diri dalam mengerjakan tugas-tugasnya, dan bertanggung jawab terhadap apa yang dilakukannya (Egok, 2016:189).

\section{METODE PENELITIAN}

Metode yang dipergunakan dalam penelitian ini adalah metode quasieksperimen. Metode ini dipilih karena kelas yang dipakai untuk perlakuan baik untuk kelas pembelajaran dengan simulasi maupun kelas pembelajaran ekspositori merupakan kelas yang sudah terbentuk sebelumnya dan karakteristik siswa yang dikontrol adalah kemandirian belajar. Desain penelitian yang digunakan dalam penelitian ini adalah faktorial $2 \times 2$. Populasi penelitian adalah seluruh siswa kelas XI SMAN 6 Pematang Siantar yang terdiri dari 6 kelas. Karakteristik siswa SMAN 6 Pematang Siantar yang tersebar dalam 6 kelas tersebut tidak dikelompokkan atas rangking dan pengelompokkan kelas unggulan tetapi penyebaran siswa ke dalam 6 kelas tersebut dilakukan secara acak saja sewaktu penempatan siswa dalam kelompok kelasnya masing-masing. terpilih sebagai kelas pembelajaran simulasi adalah kelas $\mathrm{XI}_{1}$ 
dengan jumlah 34 siswa dan Kelas $\mathrm{XI}_{3}$ sebagai kelas pembelajaran ekspositori dengan jumlah 38 siswa.

\section{TEMUAN PENELITIAN DAN PEMBAHASAN}

Rata-rata hasil belajar Pendidikan Agama Islam siswa SMAN 6 Pematang Siantar yang diajar dengan strategi pembelajaran simulasi $(\bar{X}=28,12)$ lebih tinggi daripada rata-rata hasil belajar siswa SMAN 6 Pematang Siantar yang diajar dengan strategi pembelajaran ekspositori $(\bar{X}=27,00)$.

Fakta ini menunjukkan bahwa strategi pembelajaran simulasi terbukti efektif dapat meningkatkan hasil belajar Pendidikan Agama Islam siswa SMAN 6 Pematang Siantar secara keseluruhan baik untuk kelompok siswa SMAN 6 Pematang Siantar dengan kemandirian belajar tinggi maupun kelompok siswa SMAN 6 Pematang Siantar dengan kemandirian belajar rendah.

Hal di atas dapatlah dimaklumi karena tujuan pelaksanaan strategi pembelajaran simulasi adalah membina siswa dalam rangka mengembangkan aspek kognitif, afektif dan psikomotorik siswa secara komprehensif (menyeluruh) dan berinteraksi dengan lingkungannya. Strategi pembelajaran simulasi menekankan pembelajaran di mana siswa menemukan sendiri apa yang dipelajarinya, bukan mengetahui dari guru saja.

Pelaksanaan strategi pembelajaran simulasi juga menekankan pada peran aktif dan kreatif siswa, mengingat belajar akan lebih bermakna jika fungsi kognitif, afektif, dan psikomotorik dapat bekerja bersama-sama. Dengan strategi pembelajaran simulasi, siswa belajar secara langsung dengan menyaksikan, mengamati tingkah laku strategi. Bahan penunjang pembelajarannya sangat banyak dan terdapat di sekitar siswa. Oleh karena itu, guru dapat merencanakan kegiatan pembelajaran di dalam dan di luar kelas.

Selanjutnya temuan penelitian ini juga menunjukkan rata-rata hasil belajar Pendidikan Agama Islam siswa SMAN 6 Pematang Siantar dengan kemandirian belajar tinggi $(\bar{X}=29,61)$ secara keseluruhan baik yang diajar dengan strategi pembelajaran simulasi maupun strategi pembelajaran ekspositori lebih tinggi baik daripada rata-rata hasil belajar Pendidikan Agama Islam siswa SMAN 6 Pematang Siantar dengan kemandirian belajar rendah $(\bar{X}=25,93)$. Hal ini menunjukkan bahwa kemandirian belajar tanpa memperhatikan strategi pembelajaran yang diterapkan 
berpengaruh terhadap hasil belajar Pendidikan Agama Islam siswa SMAN 6 Pematang Siantar..

Mencermati temuan di atas, maka peran guru dalam kegiatan pembelajaran adalah memperhatikan kemandirian belajar siswa sehingga strategi yang diterapkan dalam kegiatan pembelajaran sesuai dengan karakteristik kemandirian belajar siswa. Hal ini sejalan dengan penjelasan Hamalik (2009) menyatakan bahwa fungsi kemandirian adalah: (1) mendorong timbulnya tingkah laku atau perbuatan. Tanpa kemandirian tidak akan timbul suatu perbuatan, misalnya belajar, (2) kemandirian berfungsi sebagai pengarah, artinya mengarahkan perbuatan untuk mencapai tujuan yang diinginkan, dan (3) kemandirian berfungsi sebagai penggerak, artinya menggerakkan tingkah laku seseorang. Besar kecilnya kemandirian ini akan memengaruhi cepat lambatnya suatu pekerjaan/tugas dapat diselesaikan dengan baik.

Apabila diperhatikan lebih lanjut bahwa dalam strategi pembelajaran simulasi memperoleh rata-rata hasil belajar Pendidikan Agama Islam siswa SMAN 6 Pematang Siantar dengan kemandirian belajar tinggi $(\bar{X}=31,21)$ lebih tinggi daripada hasil belajar siswa SMAN 6 Pematang Siantar dengan kemandirian belajar rendah ( $\bar{X}$ = 25). Sedangkan pada strategi pembelajaran ekspositori, rata-rata hasil belajar Pendidikan Agama Islam siswa SMAN 6 Pematang Siantar dengan kemandirian belajar tinggi $(\bar{X}=28$ ) lebih tinggi daripada hasil belajar Pendidikan Agama Islam siswa dengan kemandirian belajar rendah $(\bar{X}=26,14)$. Hal ini menunjukkan bahwa kemandirian belajar signifikan untuk membedakan hasil belajar Pendidikan Agama Islam siswa, di mana hasil belajar siswa dengan kemandirian belajar tinggi baik yang diajar dengan strategi pembelajaran simulasi maupun strategi pembelajaran ekspositori lebih tinggi daripada hasil belajar dengan kemandirian belajar rendah.

Hal ini dapatlah dimaklumi karena Kemandirian belajar sebagai satu kekuatan pada diri individu dalam melakukan sesuatu tanpa tergantung orang lain tentunya mempunyai makna yang berarti bagi seorang siswa dalam merencanakan, mengelola dan menyelesaikan kegiatan belajarnya. Dapat diprediksikan bahwa apabila tingkat kemandirian seorang siswa tinggi, maka dapar diharapkan siswa tersebut akan dapat mencapai hasil yang lebih baik dari rekannya.

Temuan hasil penelitian ternyata menunjukkan semua hipotesis penelitian yaitu : (1) hasil belajar Pendidikan Agama Islam siswa SMAN 6 Pematang Siantar yang 
diajar dengan strategi pembelajaran simulasi lebih tinggi daripada hasil belajar siswa yang diajar dengan strategi pembelajaran ekspositori, (2) hasil belajar dari siswa SMAN 6 Pematang Siantar dengan kemandirian belajar tinggi lebih tinggi dari pada hasil belajar siswa dengan kemandirian belajar rendah, dan (3) terdapat interaksi strategi pembelajaran dan kemandirian belajar dalam memberikan pengaruh terhadap hasil belajar Pendidikan Agama Islam siswa, dapat diterima.

Hipotesis pertama yaitu hasil belajar Pendidikan Agama Islam siswa SMAN 6 Pematang Siantar yang diajar dengan strategi pembelajaran simulasi lebih tinggi daripada hasil belajar siswa yang diajar dengan strategi pembelajaran ekspositori. Hal ini dapat dimaklumi karena melalui strategi pembelajaran simulasi dapat mendorong siswa untuk aktif belajar karena siswa dapat menghubungkan yang mereka pelajari dengan kehidupan sehari-hari, siswa lebih banyak bertanya.

Di samping itu strategi pembelajaran simulasi bertujuan menumbuhkan partisipasi siswa dalam memecahkan isu atau masalah yang diajukan oleh guru dalam pembelajaran, menumbuhkan diskusi di antara siswa dalam mencari penyebab dan solusi terhadap isu atau masalah tersebut. Oleh karena itu peran guru dalam strategi pembelajaran simulasi lebih dominan sebagai fasilitator yang mengarahkan siswa untuk menemukan dan mengkonstruk sendiri pengetahuannya.

Pengujian hipotesis kedua menunjukkan bahwa hasil belajar dari siswa SMAN 6 Pematang Siantar dengan kemandirian belajar tinggi lebih tinggi dari pada hasil belajar dengan kemandirian belajar rendah. Hasil ini membuktikan bahwa kemandirian belajar signifikan untuk membedakan hasil belajar Pendidikan Agama Islam.

Hasil analisis data secara keseluruhan diperoleh rata-rata hasil belajar siswa dengan kemandirian belajar tinggi lebih tinggi daripada hasil belajar siswa dengan kemandirian belajar rendah. Hal ini berindikasi bahwa siswa yang dengan kemandirian belajar tinggi secara rata-rata mempunyai hasil belajar Pendidikan Agama Islam yang lebih tinggi dibandingkan dengan siswa dengan kemandirian belajar rendah. Dengan demikian siswa dengan kemandirian belajar tinggi dapat lebih memahami dan menguasai materi pelajaran Pendidikan Agama Islam dibandingkan siswa dengan kemandirian belajar rendah.

Pengujian hipotesis ketiga menunjukkan terdapat interaksi antara strategi pembelajaran dan kemandirian belajar dalam mempengaruhi hasil belajar Pendidikan Agama Islam siswa SMAN 6 Pematang Siantar. Apabila dilihat rata-rata hasil belajar 
pada kelompok siswa dengan kemandirian belajar tinggi dan diajar dengan strategi pembelajaran simulasi lebih baik dibandingkan dengan rata-rata hasil belajar kelompok siswa dengan kemandirian belajar tinggi dan diajar dengan strategi pembelajaran ekspositori.

Rata-rata hasil belajar Pendidikan Agama Islam pada kelompok siswa dengan kemandirian belajar rendah dan diajar dengan strategi pembelajaran simulasi lebih rendah dibandingkan dengan rata-rata hasil belajar Pendidikan Agama Islam kelompok siswa dengan kemandirian belajar rendah dan diajar dengan strategi pembelajaran ekspositori.

Temuan ini bermakna bahwa bagi kelompok siswa dengan kemandirian belajar rendah lebih baik diajar dengan menggunakan strategi pembelajaran ekspositori dibandingkan dengan menggunakan strategi pembelajaran simulasi. Dengan demikian dapatlah ditarik kesimpulan bahwa strategi pembelajaran dan kemandirian belajar cukup signifikan mempengaruhi hasil belajar Pendidikan Agama Islam siswa.

\section{SIMPULAN DAN REKOMENDASI}

Simpulan-simpulan yang dapat ditarik dari hasil pengujian hipotesis adalah sebagai berikut:

1. Terdapat pengaruh penerapan strategi pembelajaran simulasi terhadap hasil belajar Pendidikan Agama Islam. Hal ini terlihat dari perbedaan rata-rata hasil belajar siswa yang diajar dengan strategi pembelajaran simulasi $(\bar{X}=28,12)$ secara keseluruhan lebih tinggi dibandingkan dengan rata-rata hasil belajar siswa SMAN 6 Pematang Siantar yang diajar dengan strategi pembelajaran ekspositori $(\bar{X}=27,00)$. Dengan demikian strategi pembelajaran simulasi lebih efektif diterapkan dalam pembelajaran Pendidikan Agama Islam guna meningkatkan hasil belajar siswa tanpa memperhatikan adanya perbedaan kemandirian belajar yang dibuktikan dengan harga $\mathrm{F}_{\text {hitung }} 113,96>\mathrm{F}_{\text {tabel }} 3,984$.

2. Terdapat pengaruh kemandirian belajar terhadap hasil belajar Pendidikan Agama Islam. Hal ini terlihat dari perbedaan rata-rata hasil belajar siswa SMAN 6 Pematang Siantar dengan kemandirian belajar tinggi $(\bar{X}=29,61)$ yang diajar dengan strategi pembelajaran simulasi maupun strategi pembelajaran ekspositori lebih tinggi dibandingkan dengan rata-rata hasil belajar siswa dengan kemandirian 
belajar rendah $(\bar{X}=25,93)$. Hal ini juga dibuktikan dengan harga $F_{\text {hitung }} 7,66>$ $\mathrm{F}_{\text {tabel }} 3,984$.

3. Hasil perhitungan analisis statistik menunjukkan bahwa terdapat interaksi antara strategi pembelajaran dengan kemandirian belajar, di mana siswa dengan dengan kemandirian belajar tinggi lebih baik diajar dengan menggunakan strategi pembelajaran simulasi dibandingkan dengan menggunakan strategi pembelajaran ekspositori, sedangkan siswa dengan kemandirian belajar rendah lebih baik diajar dengan menggunakan strategi pembelajaran ekspositori dibandingkan dengan strategi pembelajaran simulasi. Hal ini dibuktikan dengan harga $F_{\text {hitung }} 35,48>$ $\mathrm{F}_{\text {tabel }} 3,984$.

Saran yang dapat disampaikan sehubungan dengan hasil penelitin ini adalah:

1. Kepada kepala sekolah agar memotivasi guru-guru khususnya guru Pendidikan Agama Islam dalam kegiatan pembelajaran untuk menerapkan strategi pembelajaran simulasi karena melalui penelitian ini terbukti dapat meningkatkan hasil belajar siswa.

2. Kepada guru agar mencermati karakteristik kemandirian belajar siswa di dalam menerapkan strategi pembelajaran simulasi dan ekspositori. Untuk siswa dengan komunikasi kemandirian belajar tinggi lebih tepat diajar dengan strategi pembelajaran simulasi sedangkan bagi siswa dengan kemandirian belajar rendah maka strategi pembelajaran yang lebih tepat diterapkan adalah strategi pembelajaran ekspositori.

3. Kepada peneliti lain yang ingin meneliti lebih lanjut tentang strategi pembelajaran simulasi hendaknya memperhatikan variabel-variabel lainnya khususnya yang berkaitan dengan karakteristik siswa seperti gaya belajar, kemampuan awal, gaya kognitif dan sebagainya sehingga diperoleh pengetahuan yang lebih komprehensif lagi.

\section{DAFTAR PUSTAKA}

Aunurrahman. Belajar Dan Pembelajaran. Bandung: Alfabeta, 2011.

Dimyati dan Moedjiono. Belajar dan Pembelajaran, Jakarta: Rineka Cipta, 1999.

Djamarah, Syaiful Bahri dan Zain, Awan. Strategi Belajar Mengajar. Jakarta: Rineka Cipta, 2002.

Gulo, W. Strategi Belajar Mengajar. Jakarta: Grasindo, 2008. 
Hamalik, Oemar.. Strategi Belajar Mengajar. Jakarta: Bumi Aksara, 1993.

Mardianto. Psikologi Pendidikan Landasan Bagi Pengembangan Strategi Pembelajaran. Bandung: Citapustaka.

Nurmawati. Evaluasi Pendidikan Islami. Bandung: Citapustaka, 2016.

Rusmono, Strategi Pembelajaran Dengan Problem Based Learning Itu Perlu Untuk Meningkatkan Porfesionalitas Guru. Bogor: Ghalia Indonesia, 2012.

Sagala, Syaiful. Konsep dan Makna Pembelajaran. Bandung: Alfabeta, 2012.

Sanjaya, Wina. Strategi Pembelajaran, Berorientasi Standar Proses Pendidikan. Jakarta: Prenada Media Group, 2014.

Siregar, Eveline dan Nara, Hartini. Teori Belajar Dan Pembelajaran. Bogor: Ghalia Indonesia, 2011.

Sopiatin, Popi dan Sahrani, Sohari. Psikologi Belajar Dalam Perspektif Islam. Bogor: Ghalia Indonesia, 2011.

Sudjana, Nana. Dasar-Dasar Proses Belajar Mengajar. Jakarta; Sinar Baru Algensindo, 2002.

Sudjana, D.S. Metode Dan Teknik Pembelajaran Partisipatif, Bandung: Falah Production, 2001.

Suparman, M. Atwi. Desain Instruksional Modern Panduang Para Pengajar Dan Inovator Pendidikan. Jakarta: Erlangga, 2012.

Syah, Muhibbin. Psikologi Pendidikan Dengan Pendekatan Baru. Bandung: Remaja Rosdakarya, 2010. 